\title{
Er det mange måter å være norsk på? \\ En empirisk studie av arbeid med minoritetsreligioner i religiøst mangfoldige barnehager
}

\author{
Av Kari-Mette Walmann Hidle og Kari Krogstad
}

The Kindergarten Framework Plan presupposes that children learn to know and respect all represented religions and worldviews as aspects of Norwegian culture. Recognition of religious festivals is a key method towards this aim. Based on a regional, mixed-methods empirical study, this article discusses kindergartens' work with minority religions. Compared to other published studies, it is found that more kindergartens recognize id al-fitr. Narratives from minority religions are also more frequently used. Yet, most kindergartens do not work systematically with the Framework Plan. Consequently, kindergartens' potential to demonstrate a paradigm of diversity against one of tolerance is discussed, and we make some practical suggestions.

Keywords: religious education $\bullet$ kindergarten $\bullet$ religious diversity $\bullet$ democratization.

Kari-Mette Walmann Hidle f. 1967. Førsteamanuensis ved Institutt for sosiologi og sosialt arbeid / Institutt for naturvitenskap, Universitetet i Agder, Postboks 422, 4604 Kristiansand.

E-post:kari.m.hidle@uia.no

KARI KROGSTAD f. 1966. Hogskolelektor i religion, livssyn og etikk ved Institutt for lacrerutdanningsfag, Høgskolen i Telemark, Postboks 203, 3901 Porsgrunn.

E-post: kari.krogstad@hit.no

NORSKE BARNEHAGER HAR

RELIGIØST MANGFOLDIGE

BARNEGRUPPER

Høy barnehagedeltakelse innebærer at flere barnegrupper er religiøst mangfoldige. Dermed økes kravet til personalets kompetanse og tilnærming. Barnehagedeltakelsen i Norge nærmer seg hundre prosent, og på 2000-tallet er det blant foreldre av ikke-vestlig bakgrunn den øker mest (Kitterød, Nymoen, \& Lyngstad 2012). I 2013 hadde 13,2 prosent av barn i norske barnehager språklig eller kulturell minoritetsbakgrunn ifølge Statistisk sentralbyrå [SSB] (2014). Som gruppe representerer ikke-vestlige innvandrere et religiøst mangfold (SSB 2014). De har statistisk sett høyere religiøs tilhørighet og deltakelse enn borgere født i Norge (Taule 2014).

I en religiøst mangfoldig barnegruppe aktualiseres spørsmålet om likeverdig behandling av forskjellige religioner og livssyn. Ifølge rammeplanen skal barnehagen bidra til at barn får interesse for hverandres bakgrunn, at de får kjennskap til tradisjoner 
knyttet til høytider i religioner og livssyn som er representert i barnegruppa, og at barna blir kjent med religion som en del av kultur og samfunn (Rammeplan for barnehagens innhold og oppgaver 2011:47).

Artikkelen er basert på en empirisk studie av hvordan barnehager i Agder, Buskerud og Telemark arbeider med minoritetsreligioner [MinRel]. ${ }^{1} 89$ prosent av respondentene oppga at de hadde en flerreligiøs barnegruppe i 2013. I lys av rammeplanens konstatering av at det er «mange måter å være norsk på », skal vi se nærmere på hvordan disse arbeidet med representerte minoritetsreligioner og -livssyn (Rammeplan 2011:8).

\section{Forskning viser lite systematisk ar- beid med rammeplanen}

Norsk institutt for forskning om oppvekst, velferd og aldring [NOVA] har undersøkt strukturell kvalitet i norske barnehager under rammeplanen fra 1995 (Gulbrandsen 2002; Gulbrandsen \& Sundnes 2004) og 2006 (Winsvold \& Gulbrandsen 2009). NOVA undersøkte også kvaliteten i 2012, etter at den nye formålsparagrafen hadde kommet (Gulbrandsen \& Eliassen 2013). Systematisk didaktisk arbeid er en forutsetning for å sikre kvalitet i det pedagogiske tilbudet (NOU 2010:24f), og NOVA har inkludert både arbeidsrutiner og planlegging som dimensjoner ved «strukturell kvalitet» i sine kvantitative undersøkelser (Gulbrandsen \& Eliassen 2013:14ff).

Rapporten Alle teller mer av Østrem m.fl. (2009) kombinerer kvantitative og kvalitative metoder og går nærmere inn på hvordan barnehager arbeider med rammeplanen. Østrem finner «en naiv tro på at fagområdene nærmest kommer av seg selv og at 'alt er fag'» (2009:139). Forskerne strever med å finne systematisk fagdidaktisk arbeid med rammeplanens fagområder i materialet. Det er få som bruker rammeplanen til planleggingsformål: $\ll \mathrm{Vi}$ får ikke inntrykk av at det legges mye planer for arbeid med fagområdene, men at man $\mathrm{i}$ etterkant av aktiviteter og temaarbeid går inn i rammeplanens tekst og sjekker hva man har jobbet med» (2009:139). Problemene synes relativt store, og rapporten konkluderer: $\ll[\mathrm{P}]$ ersonalet signaliserer usikkerhet $\mathrm{i}$ forhold til de didaktiske spørsmålene omkring fagområdene og hvordan de skal lede det pedagogiske arbeidet med et faglig innhold» (Østrem 2009:198).

Barnehagene oppgir mer systematisk arbeid i 2012 enn i 2008. I 2008 var det 55 prosent som jobbet «noe eller mye» med alle fagområder, mens tilsvarende tall for 2012 var 66 prosent. Innsatsen varierer mellom fagområdene, og i 2012 arbeidet 94 prosent av informantene «noe eller mye $\gg$ med «Kommunikasjon, språk og tekst» (89 prosent i 2008). Det er også det mest læremiddelstyrte fagområdet (Østrem 2009:198). Bare 75 prosent arbeidet «noe eller mye» med fagområdet «Etikk, religion og filosofi» [ERF] i 2012 (65 prosent i 2008). Det var ERF barnehagene arbeidet minst med (Gulbrandsen \& Eliassen 2013:51f).

Litteratursøk viser at læremiddelsituasjonen for ERF er ambivalent. Tilfanget er av forskjellige årsaker begrenset når det kommer til minoritetsreligioner og Human-Etisk Forbund [HEF]. Det finnes imidlertid en bred trosopplæringstradisjon knyttet til kristen protestantisme med bøker, musikk, film med mer. Noen av disse læremidlene er produsert med tanke på barnehager og skolers

1 Takk til Utdanningsdirektoratet for støtte til MinRel. 
behov for læremidler som formidler uten å forkynne. ${ }^{2}$ Med hensyn til hvor krevende ERF synes å være, er det påfallende at det ikke er utviklet veiledere eller materiell med tanke på en helhetlig tilnærming til fagområdet $i$ barnehagen. ${ }^{3}$

\section{Arbeid med religionsdelen av fagom- rådet $E R F$ er lite undersøkt}

De nevnte undersøkelsene fokuserer på systematikk og intensitet $\mathrm{i}$ arbeidet med rammeplanens fagområder. Det finnes også noen mindre, regionale studier som går mer i dybden på hvordan barnehagene arbeider med religionsdelen av fagområdet. De viser gjennomgående at barnehagene arbeider en del med høytider knyttet til kristendommen. Høytider tilknyttet minoritetsreligioner blir i liten grad markert, og fortellingsstoffet deres brukes knapt (Fauske 2012; Nilsen 2012). Flere av forskerne påpeker at barnehagelærernes prioriteringer innebærer en styrking av majoritetskulturen (Krogstad 2014; Rosland \& Toft 2013; Toft \& Rosland 2014; Hovdelien 2012b; Fauske 2012). Det er imidlertid i liten grad undersøkt om manglende systematisk arbeid med religioner og livssyn bidrar til å undergrave foreldreretten og dermed menneskerettighetene, slik Hovdelien drøfter i forbindelse med den nye formålsparagrafen (2012a).

Krogstad (2014) har undersøkt 250 barnehageansattes arbeid med religionsdelen av fagområdet. Hun nyanserer oppfatningen om at det generelt arbeides lite med religion: «Det gjøres mye i tilknytning til kristne høytider og merkedager, mens det arbeides lite med andre religioners høytider og merkedager» (2014:66). Respondentene vurderer følgende høytider som aktuelle å markere:
Id al-fitr og id al-adha (islam); kinesisk/vietnamesisk nyttår (buddhisme) samt divali og tamilsk nyttår (hinduisme). Foreldrebesøk i barnehagen, mat, fortellinger, musikk, drama, forming (lage gaver og pynt), arbeid med bilder og gjenstander knyttet til religionen, ekskursjon til hellige hus og prosjektarbeid er metoder som vurderes (2014:60). I praksis oppgir få respondenter at de faktisk benytter seg av dette mangfoldet av metoder. Nedenfor redegjør vi for i hvilken grad disse arbeidsmåtene blir benyttet i MinRels materiale.

\section{UNDERSØKELSEN «MINORITETS- RELIGIONER I BARNEHAGEN»}

Artikkelen er basert på en empirisk undersøkelse av praksisbarnehager tilknyttet barnehagelærerutdanningene ved Universitetet i Agder [UiA] og Høgskolen i Telemark [HiT]. Undersøkelsen har et sekvensielt og eksplorativt design der kvantitativ og kvalitativ metode kombineres (Creswell \& Plano Clark 2010). I Buskerud, Telemark, Aust- og VestAgder er det totalt 857 barnehager (Pedlex Norsk Skoleinformasjon 2014), og av disse er det 192 som har avtale med UiA og HiT om à ta imot studenter i praksis. Innledningsvis er styrere i alle de 192 tilknyttede praksisbarnehagene invitert til å svare på et kvantitativt spørreskjema. I denne sekvensen kartlegges barnegruppenes sammensetning, arbeidsmetoder knyttet til religionsdelen av fagområdet og styreres vurdering av personalets religionsfaglige kompetanse sammenliknet med barnehagens behov. Senere ble 12 pedagoger i barnehager med muslimske barn intervjuet om markering av religionens høytider, men denne artikkelen er hovedsakelig basert på undersøkelsens kvantitative sekvens.

2 Eksempelvis Kirkelig pedagogisk senter [IKO].

3 Kunnskapsdepartementets veileder «Språklig og kulturelt mangfold» (2006) fokuserer primært på språk. 
I alt besvarte 75 barnehagestyrere fra til sammen 22 kommuner i Aust- og Vest-Agder, Buskerud og Telemark spørreskjemaet. Det er ni prosent av det totale antall barnehager i de fire fylkene og 39 prosent av antall praksisbarnehager. Undersøkelsen er et bidrag til begynnende kunnskap om hvordan noen barnehager arbeider med minoritetsreligioner og prosessmålet om toleranse, respekt og interesse - et hittil lite utforsket felt. Omfanget og svarprosenten er imidlertid for lav til å kunne si noe generelt om praksisbarnehagene. For nærmere drøfting av kunnskapsbidrag i lys av begrensninger, feilkilder og konsekvenser, se Krogstad og Hidle (2015:8). Den artikkelen går også grundig inn på undersøkelsens metode og teoretiske grunnlag.

MinRel har minoritetsreligioner og livssyn i fokus. Det finnes et betydelig mangfold innen forskjellige religiøse tradisjoner. Over halvparten av medlemmene i trossamfunn utenfor Den norske kirke hører til kristne tradisjoner. Disse vier vi ikke oppmerksomhet her, siden det som nevnt allerede finnes noe forskning på barnehagers høytidsmarkering innen kristendommen. I og med at det mangler kunnskap om hvordan religioner og livssyn utenfor den kristne tradisjonen ivaretas, har vi valgt å fokusere på de fem største. Per 1.1.2013 er disse, målt etter medlemstall, islam (120 882), HEF (84300), buddhisme (16 001), hinduisme (6 797) og sikhisme (3 323) (SSB 2013).

Vi bruker uttrykket «minoritetsreligioner» med referanse til disse fem. Benevnelsen må forstås som en forenkling av det mer omfattende «de fem største minoritetsreligioner og livssyn utenfor den kristne tradisjonen, operasjonalisert gjennom tros- og livssynsamfunn som mottar offentlig støtte». Når vi inkluderer HEF i forenklingen mino- ritetsreligioner, er det ikke et uttrykk for en oppfatning om at livssynssamfunnet representerer en religion, men snarere en pragmatisk kategorisering ut fra juridiske realiteter. HEF sorterer under den samme lovgivningen som minoritetsreligionene og behandles likt med dem i rammeplanen (2011). Det finnes lite forskning på livssynshumanisme, noe som gjør det særlig viktig å inkludere HEF i utvalget.

Ser man på forholdet mellom de fem, er islam desidert størst (54\%), mens HEF (35 $\%)$ er betraktelig større enn de tre andre som tilsammen utgjør 11 prosent: buddhisme (7\%), hinduisme (3\%) og sikhisme (1\%). Regionalt er forholdstallene sammenliknbare. Vi har imidlertid ikke undersøkt alle barnehager i de aktuelle fylkene, og statistikken oppgir ikke minoritetsreligioner fordelt på alderskohorter. I 2012 fant Krogstad (2014) at de utvalgte tradisjonene var representert i HiTs praksisbarnehager i Buskerud og Telemark, men SSBs tall her kan bare antyde muligheten for at respektive minoritetsreligioner vil være representert $\mathrm{i}$ barnehagene.

Som samfunnsinstitusjon vil barnehagen bidra til å forme barn og foreldres oppfatninger om norsk kultur og premisser for fellesskap. Derfor skal vi se våre funn opp mot den plass minoritetsreligioner er gitt i barnehagens styringsdokumenter over tid. Vi begynner med en analyse av rammeplanutviklingen fra 1995 til 2011. Deretter giør vi rede for hvordan de 75 barnehagene i utvalget arbeidet med representerte minoritetsreligioner. Til slutt drøftes resultatene i lys av rammeplanutviklingen. 
MINORITETSRELIGIONER FRA «HJEMMETS KULTUR» TIL NORSK KULTUR I STYRINGSDOKUMENTENE

Markering av høytider og tradisjoner knyttet til alle religioner og kulturer representert i barnehagen ble formelt innført gjennom den første rammeplanen gjeldende fra 1996 (Rammeplan for barnehagen 1995). En forløper til dette finnes i Målrettet arbeid $i$ barnehagen: en håndbok (1982). Den vektlegger barnehagens ansvar for å sikre at alle barn blir kjent med tradisjoner knyttet til kristne høytider og merkedager som ble feiret i Norge, ut fra en tanke om at slike tradisjoner har en viktig funksjon i markering av fellesskap. Barnehagen skulle ta utgangspunkt $\mathrm{i} \ll$ de felleskulturelle sidene ved [kristne] høytider og merkedager» og fastsette innholdet i markeringene i respekt for og i samarbeid med foreldrene (1982:34f).

Håndboken stilte seg noe annerledes til andre religioner og kulturer. Her trengte man ikke sikre at alle barn ble kjent med tradisjonene, men kunne «invitere foreldre eller andre representanter fra en fremmed kultur til å arrangere fest i barnehagen» (1982:34). Barnehagen hadde ingen plikt til å gi innblikk i eller fellesskapsopplevelser knyttet til disse tradisjonene, men kunne velge å invitere. Det var så opptil de aktuelle barnas foreldre om de ønsket å ta ansvar for et arrangement. Boka speiler altså en tilnærming til mangfold. Formålet med festene blir beskrevet som todelt: «Barna fra en minoritetsgruppe [får] oppleve at det også er rom for deres skikker og tradisjoner i barnehagen, samtidig som de norske barna lærer noe nytt og får innblikk i andre folkegruppers kultur» (1982:34). For majoritetsbarna hadde aktiviteten et kunnskapsformål. De skulle få innsikt i «de andres» kultur. Minoritetsbarna skulle få erfaring med at deres kulturelle bakgrunn ble tolerert. For dem hadde aktiviteten et bekreftelsesformål.

Det er en klassisk toleransemodell som her kommer til uttrykk (Brown 2006). Fellesskapet baseres på likhet, med toleranse for en viss variasjon, og rollefordelingen mellom den tolererte og den tolerable er entydig. Den kristne protestantismen ble bekreftet som «den norske felleskulturen», en samfunnskultur i entalls form. Den ble forvaltet og videreført av barnehagen som samfunnsinstitusjon. Andre religioner og kulturer ble privatisert som «hjemmets kultur», forvaltet av den enkelte familie og tolerert av fellesskapet representert ved barnehagen. Vi skimter med andre ord en forutsetning om at protestantiske høytider tilhører det offentlige rom, mens høytider knyttet til andre religioner har sin offentlighet $\mathrm{i}$ andre land og kun tilhører privatsfæren i Norge. En slik forestilling var mer sakssvarende tidlig på 1980-tallet enn den er i dag.

I 1995 fikk barnehagene et selvstendig ansvar for «å markere høytider og tradisjoner fra andre kulturer og religioner som er representert i den enkelte barnehage» (Rammeplan 1995:70). Det understrekes at innsikt $i$ andres religion og levemåte er en forutsetning for å utvikle respekt og toleranse. Protestantisk kristendom ble fortsatt sett som premissleverandør for verdier og holdninger, men det legges til at «andre livssyn og religioner [også gir] bidrag til den norske kulturen» (1995:66). Kulturbegrepet er blitt videre og mer mangfoldig. Høytidsmarkering i andre religioner enn kristendommen får også være norsk kultur. Samtidig endres foreldrenes rolle fra å være ansvarlige for arrangementer til å bli ressurspersoner i aktiviteter som barnehagen tok ansvar for.

Rammeplanen fra 2006 understreker at «[D] et er [...] mange måter å være norsk på» (2006:7). Her fjernes minoritetsforeldrenes 
særskilte rolle knyttet til høytidsmarkering. Kravet om markering knyttet til representerte religioner og livssyn gjelder nå alle barnehager, og det er personalet som er ansvarlig for gjennomføringen. Den kristne formålsparagrafen ble problematisert i lys av menneskerettighetene i forarbeidet til ny barnehagelov. Det førte til at innholdsbestemmelsen i lovens paragraf to ble tydeliggjort, mens formålsparagrafen ble beholdt av pragmatiske hensyn. Man understreket at rammeplanen og dens prosessmål var forpliktende for alle barnehager (Ot. prp. 2005:27). Dette er helt entydig i rammeplanen: «Barnehager med særlige bestemmelser om livssynsformål er forpliktet av barnehagelovens øvrige bestemmelser, rammeplanen og regelverket for øvrig» (2006:11).

Fra 2011 er den kristne formålsparagrafen fjernet, og religioner og livssyn synliggjøres i formålet. I beskrivelsen av fagområdet ERF blir det understreket at barnehagens verdier kommer til uttrykk i mange religioner og livssyn. Der det tidligere var egne prosessmål knyttet til kristne verdier, høytider og tradisjoner, står nå høytidsmarkering og tradisjonsarbeid knyttet til kristendom og andre religioner og livssyn representert i barnegruppa i ett og samme prosessmål (2011:47).

Gjennom endringen av formålsparagrafen har man ønsket «å anerkjenne at både religioner og livssyn har en plass i det offentlige rom og at det er plass for en åndelig dimensjon i barnehagen» (Rammeplan 2011:11). Rammeplanen henviser ikke lenger til «hjemmets kultur» versus «offentlig kultur», eller at barnehagen har ansvar for kristendom, mens foreldrene har ansvar for andre religioner. Som samfunnsinstitusjon skal barnehagen reflektere, anerkjenne og gi barn kunnskap om alle representerte religioner og livssyn.

Ved å se alle religioner og høytider som feires i Norge som bidrag til den norske kulturen, blir det tydeligere at det ikke lenger er minoritetsfamilienes private kultur som eksponeres, med den fare for eksotisering som ligger i det. Religion og kultur er blitt mindre monolittiske og statiske størrelser i rammeplanen. Krogstad (2015) viser imidlertid at begreper som mangfold og det flerkulturelle fortsatt brukes som motsetning til en norsk majoritetskultur i barnehagepolitiske strategidokumenter, og at de i liten grad omtaler religion.

Formålet med markering av minoriteters høytider og tradisjoner er forskjøvet som følge av forståelsen av den norske kulturen som flerkulturell. Forskyvingen er ikke nødvendigvis så lett å få øye på. I dag inkluderes ikke minoritetsreligioner og livssyn bare av hensyn til de barna som feirer høytider hjemme, men tar eksplisitt sikte på barnegruppas demokratiske dannelse. Barn skal møte det norske samfunnet $\mathrm{i}$ barnehagen, og rammeplanen beskriver det som et samfunn preget av et mangfold av religioner, livssyn og kulturer (2011:7).

\section{BARNEHAGENE ARBEIDER IKKE}

SYSTEMATISK MED MINORITETSRELIGIONER OG -LIVSSYN

Siden kravet er at barnehagen skal arbeide med representerte religioner og livssyn, har vi undersøkt respondentenes kjennskap til brukernes tilhørighet. Av 75 respondenter oppga 55 styrere at barnehagen hadde muslimske barn, ni hadde barn med tilknytning til HEF, 14 til buddhisme, seks til hinduisme og to til sikhisme. I 11 barnehager var ingen av de oppgitte minoritetene representert. Syv barnehager oppga at ingen av minoritetsreligionene var representert, mens de ikke visste om HEF var representert. For nærmere drøfting se Krogstad og Hidle (2015:9). 
Tabell 1. Minoritetsreligioner og -livssyn i barnegruppene i 2013

\begin{tabular}{|l|r|r|r|r|r|r|r|l|}
\hline & \multicolumn{1}{l|}{$\begin{array}{l}\text { Ingen } \\
\text { barn }\end{array}$} & 1-2 barn & 3-5 barn & $\begin{array}{l}\text { Flere } \\
\text { enn 5 } \\
\text { barn }\end{array}$ & Vet ikke & $\begin{array}{l}\text { Antall } \\
\text { svar }\end{array}$ & $\begin{array}{l}\text { Data } \\
\text { mangler }\end{array}$ & Totalt \\
\hline Islam & 20 & 10 & 21 & 24 & & 75 & 0 & $\mathrm{~N}=75$ \\
HEF & 22 & 7 & & 2 & 37 & 68 & 7 & $\mathrm{~N}=75$ \\
Buddhisme & 47 & 12 & 2 & & 5 & 66 & 9 & $\mathrm{~N}=75$ \\
Hinduisme & 50 & 6 & & & 7 & 63 & 12 & $\mathrm{~N}=75$ \\
Sikhisme & 53 & 2 & & & 8 & 63 & 12 & $\mathrm{~N}=75$ \\
\hline
\end{tabular}

Styrerne ble også bedt å vurdere barnehagelærernes samlede kunnskap om religioner og livssyn i forhold til barnehagens behov. Respondentenes svar kan være gitt ut fra en vurdering av erfart eller potensielt behov. Resultatene er som følger:

Tabell 2. Egenvurdert kunnskap om minoritetsreligioner og -livssyn

\begin{tabular}{|l|r|r|r|r|r|}
\hline & \multicolumn{1}{|c|}{ Islam } & \multicolumn{1}{|c|}{ HEF } & Buddhisme & Hinduisme & \multicolumn{1}{c|}{ Sikhisme } \\
\hline Svært god & 7 & 5 & 1 & 1 & 0 \\
God & 24 & 24 & 9 & 5 & 5 \\
Middels & 37 & 32 & 26 & 21 & 15 \\
Utilstrekkelig & 4 & 3 & 23 & 29 & 34 \\
Vet ikke & 2 & 8 & 13 & 16 & 19 \\
Data mangler & 1 & 3 & 3 & 3 & 2 \\
\hline Totalt & $\mathrm{N}=75$ & $\mathrm{~N}=75$ & $\mathrm{~N}=75$ & $\mathrm{~N}=75$ & $\mathrm{~N}=75$ \\
\hline
\end{tabular}

Barnehagene vurderer sin kunnskap om islam og HEF som god. Henholdsvis fire og tre vurderer den som utilstrekkelig. 68 av respondentene angir å ha tilstrekkelig kompetanse om islam og 61 om HEF. Deretter synker kompetansen i takt med religionens forekomst i barnehagen. For buddhisme oppgir 23 styrere utilstrekkelig kompetanse, mens tilsvarende tall er 29 for hinduisme og 34 for sikhisme. Likefullt vurderer 20 av respondentene barnehagelærernes samlede kompetanse om sikhisme som tilstrekkelig, 36 har tilstrekkelig kompetanse om buddhisme, og 27 om hinduisme. Oppsummert anser respondentene sine barnehager som relativt godt rustet i møte med minoritetsreligionene. De vurderer samlet kunnskap som tilstrekkelig i forhold til behovet.
I spørreskjemaet ble informantene bedt om å angi hvilke av følgende metoder de benyttet $\mathrm{i}$ arbeidet med prosessmålene om religioner og livssyn i 2013: Fortelling; sang/ musikk; forming; ekskursjon; besøk i barnehagen; digitalt arbeid eller annet. Metodene er hentet fra Krogstad (2014:59) og supplert med alternativene digitalt arbeid og annet. Det er et gjennomgående trekk at barnehagene ikke arbeider metodisk med representerte minoritetsreligioner slik rammeplanen krever, samtidig som de oppgir å ha tilstrekkelig kompetanse på den aktuelle religionen/ livssynet. Mangelen på systematisk arbeid er i tråd med tidligere omtalte forskningsresultater. Nedenfor presenteres resultatene systematisert etter religion og livssyn. 


\section{Islam er den minoritetsreligionen barnehagene arbeider mest med}

Islam er den minoritetsreligionen som oftest er representert i utvalget, derfor begynner vi med den. Vi skal se på hvilke arbeidsmetoder barnehagelærere bruker til å reflektere islam og gi barna kunnskap om og skape interesse for venners muslimske bakgrunn.

55 av 75 barnehager oppga at de hadde muslimske barn i 2013. Av disse markerte 21 id. Til tross for at kun tre barnehager med muslimske barn vurderte sin kompetanse på islam som utilstrekkelig, unnlot 34 å markere muslimske høytider. Andelen som gjennomførte høytidsmarkering var altså lav, men den øker noe med høyere egenvurdert kompetanse. Av seks styrere som oppgir «svært god» kompetanse og som har muslimske barn, markerte fire id al-fitr. Tilsvarende markerte nesten halvparten av de som rapporterte «god» kompetanse, id, 11 av 24 styrere. Blant de som oppga «middels» kunnskap, markerte seks av 24 høytiden.

De som markerte id, brukte flere metoder: 19 oppga fortelling; 11 musikk; tre forming, én ekskursjon; fire besøk; fire digitalt arbeid, og åtte krysset av for «annet». Trolig er flere av disse arbeidsmåtene brukt i forbindelse med høytidsmarkeringen.

Tilrettelegging for læring om religioner og stimulering av barns interesse for hverandres bakgrunn kan gjøres på mange måter. $11 \mathrm{av}$ de 55 barnehagene som hadde muslimske barn i 2013, oppgir ingen arbeidsmetoder $i$ arbeidet med å reflektere islam. Av disse vurderer bare to barnehagens kompetanse om religionen som «utilstrekkelig». Syv vurderer kompetansen som «middels» og to «god» i forhold til barnehagens behov.

Fortelling er den arbeidsmetoden som brukes mest. Av de 44 barnehagene som oppgir aktivitet knyttet til islam, oppga 38 at de brukte fortelling. Sammenliknet med Fauske (2012), som fant at tre barnehager (eller én prosent) i Møre og Romsdal brukte fortellinger fra andre religioner enn kristendommen, er dette et høyt tall. Forøvrig brukte 22 sang/ musikk, åtte forming, to ekskursjon, mens åtte hadde besøk i barnehagen og 17 krysset av for annet. «Annet» utdypes ofte som mat. Foreldre bringer festmat til barnehagen, eller personalet serverer noe som er knyttet til en region/tradisjon. De to som brukte ekskursjoner, besøkte den lokale moskeen, og de er blant dem som har over fem barn.

Det ser ut til å være en viss sammenheng mellom antall muslimske barn og synliggiøring av religionen $\mathrm{i}$ barnehagen. Blant de 24 informantene som oppgir flere enn fem muslimske barn, svarer 15 at de bruker fortelling, og 12 barnehager markerte id. Tilsvarende markerte bare en av 11 barnehager med 1-2 muslimske barn id. Intuitivt kan det tenkes at barnehagen øker sin kunnskap og bevissthet om islam gjennom erfaring. Dersom de jevnlig har flere barn med muslimsk bakgrunn, gir det tid til å bygge kunnskap i organisasjonen. Med hensyn til barnet vil sårbarheten være større der ett barn er alene som representant for en religion i gruppa. Da er det enda viktigere at personalet sikrer den nødvendige aktivitet på området.

\section{God egenvurdert kompetanse, men lite aktivitet knyttet til humanetikk}

$\mathrm{Ni}$ av 75 barnehager oppga at de hadde barn med tilknytning til HEF. Syv barnehager hadde 1-2 barn med denne tilhørigheten, mens to oppga at de hadde flere enn fem barn. 22 svarte at de ikke hadde barn med tilknytning til HEF, 37 informanter krysset av for «vet ikke», mens syv unnlot å svare på spørsmålet. Det er altså stor usikkerhet om barns tilknytning til livssynet. 
Mens 37 informanter ikke vet om de har barn med tilknytning til HEF i barnegruppa, oppgir fem at de ikke vet om deres barn er buddhister. Det tilsvarende tallet for hinduer og sikher er syv og åtte, mens ingen oppgir usikkerhet om barna er muslimer. Når usikkerheten omkring tilknytning til HEF er så stor, kan det ha sammenheng med en tilnærming til religioner og livssyn som er orientert mot restriksjoner og ytre kjennetegn på tilhørighet.

HEF har vært prinsipielle motstandere av at barn skal ha medlemskap i tros- og livssynssamfunn (Knutsen m.fl. 2006). I barnehagesammenheng er det imidlertid ikke registrert medlemskap som er interessant, men det verdensbildet barnet har med seg hjemmefra. Det kan likevel ikke utelukkes at noen styreres usikkerhet på dette området kan ha sammenheng med HEFs prinsipielle holdning. I samfunnsdebatten har HEF som livssynssamfunn vært profilert i forhold til religionsfrihet i offentlige institusjoner. Det gjelder ikke minst med tanke på spørsmål knyttet til trosopplæring og forkynnelse i barnehage og skole. Gitt en slik kontekst er det interessant at bare ni av 75 barnehager forholder seg til familiers tilknytning til HEF.

HEF har ikke helligdager og årvisse festdager slik vi finner i religionene. Livssynssamfunnet gjennomfører imidlertid livsritefeiringer som navnefest, konfirmasjon, bryllup og begravelse. Disse vil være viktige i barns liv. Heller ikke for HEF var det slik at barnehagene systematisk synliggjorde livssynet dersom det var representert i barnegruppa. Av de syv som hadde 1-2 barn tilknyttet HEF, var det fire som ikke brukte noen arbeidsmetoder. Én oppga fortelling, digitalt arbeid og annet, en annen brukte fortelling, sang og annet, mens den tredje kun brukte fortelling. Tilsvarende oppga den ene barnehagen med flere enn fem humanetikere ingen metoder, mens den andre hadde brukt fortelling, sang/musikk og forming.

\section{Barnehagelærere arbeider lite med buddhisme, hinduisme og sikhisme}

Statistisk sett er det langt færre buddhister enn muslimer og humanetikere i Norge. I de fire fylkene som var representert i undersøkelsen, var det tilsammen 2312 registrerte medlemmer i buddhistiske trossamfunn i 2013. Tilsvarende tall for livssyn er 10 647, hvorav drøyt 97 prosent tilhører HEF (SSB 2013). Derfor er det overraskende at nesten dobbelt så mange barnehager oppgir å ha buddhistiske barn som barn knyttet til HEF, altså 14 barnehager. Mens fem ikke vet, oppgir 47 barnehager at de ikke har barn med tilknytning til buddhisme. Under halvparten av barnehagene (36 av 75) oppgir å ha «tilstrekkelig» kompetanse på buddhisme. Én oppgir «svært god» kompetanse, ni $\ll \operatorname{god} \gg$ og $26 \ll$ middels $\gg$.

I materialet var ingen buddhistiske barn sammen med mange andre med samme religion i barnehagen. To enheter hadde 3-5 buddhistiske barn. De oppga å ha «middels» kunnskap om religionen. Den ene brukte ingen metoder knyttet til buddhisme, den andre brukte musikk og annet, uten at sistnevnte ble utdypet.

De øvrige buddhistiske barna var alene eller sammen med ett annet buddhistisk barn. De gikki 12 forskjellige barnehager som oppga at de hadde enten «god» (fire barnehager), «middels $»$ (seks), eller «utilstrekkelig» (to) kunnskap om buddhisme. Fem av disse oppgav ingen arbeidsmetoder knyttet til buddhisme. Av de syv andre gjennomførte én høytidsmarkering knyttet til vietnamesisk nyttår og brukte fortelling, tre andre fortalte også. I tillegg ble det brukt musikk, besøk og digitalt arbeid. 
Vurdert ut fra dette begrensete materialet er det altså lite trolig at barn som går i barnehage sammen med buddhistiske barn, får kjennskap til buddhismen og dens høytider og tradisjoner. Dersom familien ikke bruker norsk i hjemmet, kan barnet mangle relevante norske begreper og erfare at det ikke kan dele denne delen av sitt liv med omgivelsene.

Det er et svært begrenset antall registrerte hinduer i Norge. Ved inngangen til 2013 var 1,3 prosent av medlemmer i tros- og livssynssamfunn utenfor Den norske kirke hinduer (6 797 medlemmer). Tallet er ikke er brutt ned på fylkesnivå (SSB 2013). I materialet oppgir seks barnehager at de hadde hinduer $\mathrm{i}$ barnegruppa i 2013, 50 oppgir at de ikke har, syv vet ikke og 12 svarer ikke på spørsmålet.

De seks barnehagene har 1-2 hinduistiske barn hver. To av disse brukte fortelling og musikk, mens den ene i tillegg hadde besøk i barnehagen. De resterende fire oppga ingen arbeidsmetoder. Fem barnehager som ikke hadde barn knyttet til hinduisme, oppga at de arbeidet med denne religionen i 2013.

Kunnskapen om hinduisme er lavere enn for islam, HEF og buddhisme. Tilsammen oppgir bare 27 barnehager at deres kunnskap om hinduisme er tilstrekkelig, henholdsvis én «svært god», fem «god» og $21 \ll$ middels $\gg$. 29 oppgir at barnehagens kunnskap om religionen er «utilstrekkelig». I tillegg svarer 16 《vet ikke», mens tre unnlater å svare på spørsmålet om kompetanse på hinduisme.

I følge SSB ble det utbetalt støtte for 3 323 sikher i 2013, og de utgjør 0,6 prosent av trossamfunnsmedlemmer utenfor Den norske kirke. Heller ikke sikhene opplever å ha mange lekekamerater med samme bakgrunn i barnehagen. I vårt materiale opplyser to barnehager at de har 1-2 barn tilknyttet sikhisme.

Det er lite kompetanse om religionen i utvalget. Bare 20 av respondentene mener at deres barnehage har tilstrekkelig kompetanse: fem oppgir «god» og $15 \ll$ middels» kunnskap. 34 barnehager vurderer sin kunnskap som «utilstrekkelig», 19 «vet ikke», og to besvarer ikke spørsmålet. Det har trolig sammenheng med det erfarte behovet. 53 oppgir at de ikke har barn med denne religionen, åtte krysser av for «ikke vet», mens 12 respondenter ikke besvarer spørsmålet.

Til tross for at tre av barnehagene som har barn knyttet til sikhisme i barnegruppa, oppgir å ha «god» eller «middels» kompetanse om religionen, gjennomfører ingen av dem høytidsmarkering eller andre aktiviteter knyttet til tradisjonen.

\section{Mer høytidsmarkering og bruk av religiøse fortellinger enn i andre undersøkelser}

Barnehagene i utvalget arbeider i liten grad systematisk med representerte minoritetsreligioner. Forekomsten av høytidsmarkering og fortellinger fra minoritetsreligioner $i$ dette materialet er likevel høy sammenliknet med tidligere forskning (Fauske 2012; Nilsen 2012; Rosland \& Toft 2013; Toft \& Rosland 2014). For islam ser markering av id al-fitr ut til å være innarbeidet i en del barnehager, det samme gjelder bruk av fortellinger fra muslimske tradisjoner. Når det er sagt, markerte ingen av barnehagene flere enn én høytid for samme minoritetsreligion. De som ikke gjennomfører høytidsmarkering, ser i beskjeden grad ut til å kompensere for dette gjennom andre metoder. Dermed opplever barn i liten grad å bli kjent med sine venners religiøse bakgrunn i barnehagen. Det gjelder særlig hvis religionen er lite utbredt i barnegruppa. Konkrete aktiviteter er mer vanlig når det er flere barn med samme minoritetsreligion i en barnehage. 
MAKTER BARNEHAGEN A DEMONSTRERE AT DET ER MANGE MÅTER Å VÆRE NORSK PÅ?

Tidligere forskning har vist at profesjonen $\mathrm{i}$ liten grad arbeider systematisk med rammeplanen og bruker den til planleggingsformål. Høytidsmarkering er relativt planleggingsintensivt, og mangel på systematikk kan slå sterkt ut på denne delen av fagområdet. Et slikt perspektiv kan bidra til å forklare hvorfor barnehagene i MinRel vurderer sin kompetanse som tilstrekkelig, samtidig som de ikke jobber aktivt med minoritetsreligioner og livssyn som er representert i barnehagen. Ferdig produsert og helhetlig materiell vil kunne være en god støtte for mange barnehager når det gjelder arbeidsmetoder.

Den lave egenrapporterte aktiviteten kan også ha sammenheng med misforståelser knyttet til verdier og prosessmål i styringsdokumentene. Den påviste endringen i barnehagens rammeplan, der minoritetsreligioner går fra å være «hjemmets kultur» til å være en måte å være norsk på, kan være vanskelig å fange opp. Det undersøkte materialet ser i liten grad ut til å speile styringsdokumentenes endring på dette punktet. Det er få spor av at høytider og tradisjoner fra andre religioner enn kristendommen får være norsk kultur i barnehagene. Det kan ha sammenheng med manglende forståelse av planens tilnærming til mangfold.

Våre informanter var lite opptatt av minoritetsreligioner og livssyn som en del av mangfoldskulturen barn skal bli kjent med og veves inn i. Heller ikke de informantene som gjennomførte eller ønsket å komme i gang med høytidsmarkering, var opptatt av høytidsmarkeringenes sosialiseringsfunksjon (Krogstad \& Hidle 2015:10). Det er grunn til å spørre om barnehagene fortsatt formidler en toleransemodell der minoritetsreligioner og livssyn blir tålt, men ikke anerkjennes som del av «den norske felleskulturen». Det kan være en av årsakene til manglende oppslutning om høytidsmarkering hos personell og minoritetsreligiøse foreldre (Krogstad \& Hidle 2015:12).

Ikke alle opplever at det er mange måter å være norsk på i barnehagen. I det kvalitative materialet fant vi at flere betraktet islam som familienes private eiendom. En eventuell høytidsmarkering ble betraktet som noe foreldrene skulle forvalte alene. Siktemålet med markeringene ble oppfattet som ensidig å være knyttet til det muslimske barnets identitet. Noen informanter refererte til eget og foreldres ubehag knyttet til arbeid med prosessmålet. Utsagn fra samtaler om dette viste at ønske om høytidsmarkering ble markert som motsetning til å være «norsk», «vanlig» og så videre gjennom språket (Krogstad \& Hidle 2015:10ff). For at barnehagene skal kunne arbeide med minoritetsreligioner på en hensiktsmessig måte, må slike konflikter avklares. Det kan for eksempel gjøres i form av en veileder.

Det kan se ut til at rammeplanens spiralprinsipp - tanken om at barna først skal møte de religionene som er representert i barnegruppa - bidrar til å fastholde institusjonen i det paradigmet vi finner i håndboka fra 1982. Bestemmelsen om at det kun er minoritetsreligioner som er representerte i barnegruppa, som skal markeres, kan bidra til å sementere toleransemodellens oppfatning om minoritetsreligioner som noe privat - en $\ll$ hjemmets kultur» som skal tåles. For å styrke kulturen for høytidsmarkering og arbeid med livstolkningsressurser, kan det vurderes å innføre en foreløpig ordning der barnehagene skal arbeide årlig med et fast knippe minoritetsreligioner i en periode på eksempelvis fem år. 
$\AA$ arbeide med tre religioner og livssyn i tillegg til kristendom vil være et godt løft. Ved å velge de tre ut fra representasjon på fylkesnivå, sikres lokal representasjon. Det er viktig, da barnehagen har lokalsamfunnet som sitt læringssted. Slik vil arbeid med HEF også ivaretas. Det synes viktig i lys av undersøkelsen, og med tanke på livssynssamfunnets utbredelse og samfunnsmessige betydning.

Ut fra kunnskapsstatus om barnehagenes arbeid med rammeplanen generelt og religiøst mangfold spesielt, kan det være grunn til å reflektere over lovgivers forventninger til institusjonen. Barnehagen har utvilsomt potensiale til å bidra til samhold og gjensidighet $i$ en mangfoldig norsk kultur. Men situasjonen gir grunn til å vurdere om, og eventuelt hva som skal til for at barnehagelærerne skal kunne være fortropp i å utvikle nye tilnærminger og arbeidsmåter i møte med samfunnsendringene. Slikt arbeid krever tid og fordypning. Det må være balanse mellom bredden i barnehagelærerens oppgaver, faglig dybde og tilgjengelige ressurser på den ene siden, og kompetanse på den andre. Enhver diskusjon om rammeplanens innhold og ambisjonsnivå forutsetter imidlertid at profesjonen faktisk forholder seg til de føringer styringsdokumentene gir. Her er den gordiske knuten. Det trengs samarbeid mellom flere barnehagepolitiske aktører for å løse den.
LITTERATUR

Andersen, Camilla Eline \& Sigrun Sand (red.). 2012. Utforsking av flerkulturelle praksiser $i$ barnehagen: idéhefte med erfaringer, refleksjoner og ideer fra forskningsprosjektet «Den flerkulturelle barnehagen i rurale strøk». Vallset: Oplandske bokforlag.

Brown, Wendy. 2006. Regulating aversion: tolerance in the age of identity and empire. Princeton: Princeton University Press.

Creswell, John W. \& Vicki L. Plano Clark. 2010. Designing and conducting mixed methods research (2. utg.). Los Angeles: Sage.

Fauske, Ragnhild. 2012. Bruken av religiøse forteljingar i barnehagen. Norsk tradisjon og manglande fleirreligiøsitet. Prismet, 63 (1), 35-57.

Gulbrandsen, Lars \& Erik Eliassen. 2013. Kvalitet $i$ barnehager: rapport fra en undersøkelse av strukturell kvalitet høsten 2012 (NOVA-rapport nr. 1/2013). Oslo: Norsk institutt for forskning om oppvekst, velferd og aldring.

Gulbrandsen, Lars. 2002. Kvalitetssatsing $i$ norske barnehager. Statusrapport midtveis (NOVA-rapport nr 2/2002). Oslo: Norsk institutt for forskning om oppvekst, velferd og aldring.

Gulbrandsen, Lars og Anita Sundnes. 2004. Fra best til bedre? Kvalitetssatsing i norske barnehager. Statusrapport ved kvalitetssatsingsperiodens slutt. (NOVA-rapport nr. 9/2004). Oslo: Norsk institutt for forskning om oppvekst, velferd og aldring.

Hovdelien, Olav. 2012a. Barnehagens formålsparagraf - hvordan skal den forstås? Prismet, $63(2-3), 105-113$.

Hovdelien, Olav. 2012b. Kulturelt mangfold i barnehagen: et bidrag til begrepsforståelsen. I Ann Merete Otterstad og Nina Rossholt (red.). Barnehagelarerutdanningens kompleksitet: bevegelser i faglige perspektiver (s. 97-112). Oslo: Universitetsforlaget. 
Kitterød, Ragni Hege, Erik H. Nymoen og Jan Lyngstad. 2012. Endringer i bruk av barnetilsyn fra 2002 til 2010: tabellrapport. Hentet fra http://www.ssb.no/utdanning/artiklerog-publikasjoner/endringer-i-bruk-av-barnetilsyn-fra-2002-til-2010

Knutsen, Paul, Terje Emberland og HumanEtisk Forbund. 2006. Livet før døden: Human-etisk forbund 1956-2006. Oslo: Humanist forlag.

Krogstad, Kari. 2014. Høytidsmarkering i barnehagen. FoU i praksis, 8 (2), 51-69.

Krogstad, Kari. 2015. På leting etter religion En diskursanalyse av begrepet «det flerkulturelle» i politiske tekster om barnehage. Norsk pedagogisk tidsskrift, 99 (1), 3-14.

Krogstad, Kari \& Kari-Mette Walmann Hidle. 2015. Høytidsmarkering i religiøst mangfoldige barnehager. Nordisk barnehageforskning, 9 (6), 1-17.

Målrettet arbeid i barnehagen: en håndbok. 1982. Nilsen, Tina Dykesteen. 2012. Barnehagen - kultur for læring om religioner og livssyn? I Torill Vist \& Marit Alvestad (red.), Laringskulturer $i$ barnehagen: flerfaglige forskningsperspektiver (s. 239-260). Oslo: Cappelen Damm akademisk.

Ot.prp. nr. 72 (2004-2005). 2005. Om lov om barnehager. Oslo: Barne- og familiedepartementet.

NOU 2010:8. (2010). Med forskertrang og lekelyst - Systematisk pedagogisk tilbud til alle førskolebarn. Oslo: Departementenes servicesenter, Informasjonsforvaltning.

Pedlex Norsk Skoleinformasjon (2014). Hentet fra http://skoleadresser.no/4daction/WA Pedlex_Grupper/?R_Time $=090123 \& \mathrm{ramp}$ ;Gr=930_950_955_960\&amp;Tittel=Alle barnehager\&amp;Find=\&amp;Bokstaver= Rammeplan for barnehagen. 1995.

Rammeplan for barnehagens innhold og oppgaver. 2006.
Rammeplan for barnehagens innhold og oppgaver. 2011.

Rosland, Kristine Toft \& Audun Toft. 2013. Markering av minoriteters høytider i barnehagen. En undersøkelse av forholdet mellom rammeplan og praksis. I Ingar Pareliussen, Bente Bolme Moen, Anne Beate Reinertsen \& Trond Solhaug. FoU $i$ praksis 2012: conference proceedings (pp. 216-213). Trondheim: Akademika forlag.

Statistisk sentralbyrå. 2013. Trus- og livssynssamfunn utanfor Den norske kyrkja, 1. januar 2013. Hentet fra https://www.ssb. no/kultur-og-fritid/statistikker/trosamf/ aar/2013-12-04

Statistisk sentralbyrå. 2014. Barn i barnehager fra språklige og kulturelle minoriteter. Fylke. 2013. Hentet fra https://http:// www.ssb.no/a/barnogunge/2014/tabeller/barnehage/bhage0600.html

Taule, Liv. 2014. Norge - et sekulært samfunn? Samfunnsspeilet, 1/2014. Hentet fra http:// www.ssb.no/kultur-og-fritid/artikler-ogpublikasjoner/_attachment/164168? ts $=144 \mathrm{de} 41 \mathrm{~b} 4 \mathrm{e} 0$

Toft, Audun \& Kristine Toft Rosland. 2014. Barnehager og høytidsmarkering. Prismet 65 (4), 211-225.

Winsvold, Aina \& Lars Gulbrandsen. 2009. Kvalitet og kvantitet. Kvalitet $i$ en barnehagesektor $i$ sterk vekst (NOVA-rapport nr. 2/2009). Oslo: Norsk institutt for forskning om oppvekst, velferd og aldring.

Østrem, Solveig, Harald Bjar, Line Rønning Føsker, Hilde Dehnæs Hogsnes, Turid Thorsby Jansen, Solveig Nordtømme \& Kristin Rydjord Tholin. 2009. Alle teller mer. En evaluering av hvordan Rammeplan for barnehagens innhold og oppgaver blir innført, brukt og erfart. (Rapport nr. 1/2009). Tønsberg: Høgskolen i Vestfold. 